\title{
Study on the Judicial Application of the Crime of Preparing to Commit Terrorist Activities in Chinese Criminal Law*
}

\author{
Gang Luo \\ Law School \\ Xinjiang University \\ Urumqi, China 830046
}

\begin{abstract}
The Crime of Preparing to Commit Terrorist Activities is added in China's Criminal Law Amendment (IX), which disposes of acts of preparing weapons, dangerous goods or other tools for terrorist activities, organizing terrorist training or actively participating in training for terrorist activities, connecting with overseas terrorist organizations or personnel to commit terrorist activities, and planning or making other preparations for terrorist activities as crimes. The establishment of new crimes is of great significance for China in punishing terrorist activities. The accurate understanding and grasp of this crime determines the effect of the anti-terrorism criminal justice practice in China, and therefore in-depth study on behavioral patterns, subjective aspects, and other important issues must be conducted.
\end{abstract}

Keywords-crime of preparing to commit terrorist activities; preparatory acts; combined punishment for several crimes

\section{INTRODUCTION}

In order to meet the needs of cracking down on terrorist activities, China's Criminal Law Amendment (IX) stipulates directly the act of preparing to commit terrorist activities as a crime. Although preparatory acts can be punished as the preparatory crimes of specific terrorist activities according to the general provisions of the criminal law, under normal circumstances, the punishment is too light and it's difficult to reflect the evaluation of the responsibility of above-mentioned acts; at the same time, in anti-terrorism activities, the specific terrorist activities are often discovered and detected before planning, however, it is difficult to identify which specific crimes they are prepared to commit, so they cannot be convicted or punished. Particularly there has been "lone-wolf" and interim terrorist organizations, which are difficult to be identifies as terrorist organization and cannot be convicted and punished as preparatory crime for organizing, leading, and participating in terrorist organizations. "The crime of preparing to commit terrorist activities" is to punish criminal preparation

*This article presents the phased research results of the "Study on Foreign Anti-Terrorism Governance" (No.BS160108) I preside over in the Doctoral Initial Foundation for Xinjiang University, and the "Study AntiTerrorism Mechanism in Urban Public Transportation of Xinjiang" (No.XJEDU010915A01), which is a major project in key research of liberal arts of regular institutions of higher learning in Xinjiang Uyghur Autonomous Region. as an independent crime. Only in this way can we effectively curb and prevent the occurrence of major and vicious terrorist incidents.

\section{OBJECTIVE IDENTIFICATION OF CRIMES IN FOUR SITUATIONS}

In judicial practice, the key to applying the crime lies in correct understanding of its four situations.

The first case: "Preparing weapons, dangerous goods, or other tools for terrorist activities". The "weapon" can be judged according to the provisions in the Interpretation of Several Issues Concerning the Application of Law in Handling Criminal Cases of Theft issued by the Supreme People's Court and Supreme People's Procuratorate of the People's Republic of China on April 2nd, 2013, namely "guns, explosives, controlled knives, and other devices prohibited from being carried by individuals, and other devices that are sufficient to endanger the personal safety of others to commit crimes". It includes not only instrument controlled by the state (the instrument itself belongs to the state control category, such as guns, explosives, controlled knives, and other devices prohibited from being carried by individuals), but also includes equipment that can endanger the personal safety of others, such as ice pitons, spikes, hammers, and bricks. There are no provisions for the so-called "dangerous goods" that can be referred to in the criminal law and its related interpretations. We cannot simply apply the explanation of "dangerous goods" in the crime of causing an accident with dangerous goods in the Interpretation of Several Issues Concerning the Criminal Punishment in the Implementation (Railway Law) promulgated by the Supreme People's Court in October 1993. Considering the behavioral pattern of terrorist activities, the goods that can cause serious injury or death to others can be regarded as dangerous goods, including but not limited to poisons, toxic gases, gasoline, diesel, strong acids, etc. It should be noted that it cannot be convicted based on the preparation of these goods, but it is also necessary to prove that the actor prepares these goods to commit terrorist activities. "Other devices" do not only refer to devices with equal danger as the abovementioned weapons and dangerous goods, but should also include goods that can facilitate the crime of terrorist activities, or help improve the ability to commit violent terrorist activities, 
such as vehicles, mobile phones and other communication tools, maps, and compasses. The act of preparing tools and goods includes the manufacture, purchase, transportation, storage, experiment, and all other activities that prepare tools and goods for terrorist activities.

The second situation: "Organizing terrorist training or actively participating in training for terrorist activities". It mainly includes arranging teachers, boarding and lodging, organizing trainees, organizing training courses, and teaching in person for terrorist activities, using information networks such as the Internet to run training classes, organizing discussions, and so on. The content of training is not limited, which not only includes things in the spiritual field such as thoughts, concepts, and opinions about terrorism, but also includes methods, skills, means, physical training, actual combat training, manufacturing methods of crime tools, etc., to commit specific terrorist activities. According to the provision of this situation, non-organizational acts or acts that only provide general assistance for the training of terrorist activities, forced or inveigled to participate in terrorist training, cannot be convicted according to this situation. The act of providing financial aid for training while organizing training of terrorist activities shall be convicted and punished in accordance with the crime of preparing to commit terrorist activities. The act of organizing terrorist training or actively participating in training for terrorist activities while organizing, leading, and participating in terrorist organizations constitutes crimes of organizing, leading, participating in terrorist organizations, and preparing to commit terrorist activities at the same time, which is convicted and punished in accordance with the heavier penalty regulations. In the training process, the act of inciting to split the country and subvert state power is also convicted and punished in accordance with the heavier penalties.

The third situation: "Contacting overseas terrorist organizations or personnel to commit terrorist activities", including direct and indirect contacts. Contact way includes, but is not limited to, phone, email, letter, meeting, etc. The purpose of contact is to commit terrorist activities. If it is not for this purpose, it cannot be convicted according to this situation. "Committing terrorist activities" should be understood in broad sense, including not only committing specific terrorist activities such as killings, explosions, and kidnappings, but also preparing for and helping terrorist activities, such as participating in training for terrorist activities and seeking material assistance, intelligence information for terrorist activities. The so-called "overseas terrorist organizations" refer to terrorist organizations or their branches in countries or regions outside the borders of the People's Republic of China. To judge whether a terrorist organization is an "overseas terrorist organization", it not only needs to see whether its geographical location is in China, but it is also necessary to consider the main scope of activities of this organization, as well as the locations of its so-called headquarter and main members. "Overseas terrorist activities individuals" refer to foreign citizens or stateless persons who are not affiliated with any overseas terrorist organization. If it can be proved that the actor communicates for the purpose of committing terrorist activities, there is no significance for the distinction between contact and connection; however, if there are many cases, such problems may arise in which the actor is a terrorist and is in contact with overseas terrorist organizations and personnel, but the content of the contact cannot be determined. At this time, in order to prevent the abuse of penalty and maintain the objectivism of criminal law, it cannot be concluded that terrorist in contact with an overseas terrorist organization is deemed to commit the crime. In fact, the Criminal Law Amendment (IX) made a textual adjustment during the deliberation process and changed "contact" to "connect." This is not meaningless, nor is it like believed by some scholars that "generally, both 'contact' and 'connection' can be used as verbs in grammar, between which "contact" is more abstract, while "connection" is more concrete. It is more appropriate to use "connection" in the statute of this crime. However, in general, this is only a minor change with little impact." ${ }^{1}$ I believe that contact and connection are two different concepts in light of the overall consideration of the situation and the spirit of legislation. Contact can be said to be the communication in daily life, while connection is aimed at specific affairs. In this crime, it is the communication for committing terrorist activities, the expression of intentions, and the formation of consensus. Abandoning the contact as a daily life term, the general interpersonal contacts are excluded from the crime. Therefore, in order to avoid abuse of penalties, "connection" should be strictly limited, that is, only the connection with "content directly related to terrorist activities committing" can be convicted as a crime.

The fourth situation: 'and planning or making other preparations for terrorist activities as crimes". "Planning" refers to the formulation of plans for terrorist activities, the selection of target, place, and time for committing terrorist activities and the assignment of tasks for terrorist activities. This is a miscellaneous provision, but there are different opinions on understanding. Some people think that "other preparations" should be limited to the miscellaneous provision in Article VI, and therefore they should be limited to planning of terrorist activities or equivalent preparations. Professor Zhang Mingkai believes that "other preparations" are the miscellaneous provisions in Paragraph 1 of Article 120-2. ${ }^{2}$ This controversy has practical significance. Two different understandings will lead to different sizes of crime circles set by this statute. I agree with Professor Zhang Mingkai's point of view that the "other preparations" must directly apply the provisions of Paragraph 1, Article 120-2 of the Criminal Law, and punishment is directly decided according to the provisions of this paragraph, without having to apply the provisions of the General Principles of Criminal Law concerning subordinate preparatory crimes. The purpose of the amendment's normative setting on crimes of terrorist activities is to strengthen the crackdown on crimes of terrorist activities rather than the opposite. In order to maintain a tight legal network and achieve balance with other acts in penalty processing, it is more appropriate to consider it as the miscellaneous provision of Paragraph 1. Therefore, in judicial

Chief Editor: Zhao Bingzhi, Understanding and Application of the Criminal Law Amendment of the People's Republic of China (XI). China Legal Publishing House, 2016.112.

Zhang Mingkai. On the provisions of the Criminal Law Amendment (IX) on terrorist crimes [J]. Modern Law Science, 2016, 38(01):29.] 
practice, preparations for terrorist activities that are not specified in Paragraph 1 can be handled as this crime.

Special attention should be paid to the fact that the interpretation of constitutive elements must still prevent the generalization of incrimination. Legislators establish this crime for they recognize the necessity of controlling preparatory act: once a terrorist crime is successfully committed, the harm caused is immeasurable. The anti-terrorism strike-hard criminal policy therefore requires to focus on prevention, combine punishment and prevention, anticipate enemies, keep initiative, strongly intervene in the preparatory and planning stage of terror activities, prevent the occurrence of terrorist activities and obtain maximum security at the lowest cost. In past judicial practice, the acts of planning and preparing for terrorist activities in early stage were mostly handled as preparation for a crime, which had obvious limitations, and the deterrence of penalty was insufficient, so it failed to highlight the core anti-terrorism idea of preventing and controlling terrorist activities in the preparatory stage. However, it is necessary to note at the same time that this crime has to overcome the drawbacks of the irrational expansion of the crime circle caused by the preparation of crimes, although the range of punishment is limited by establishing the four types of acts, including "preparing weapons, dangerous goods or other tools, organizing and participating in training, connecting with overseas terrorist organizations or personnel, and planning". Some scholars think it is successful overall. ${ }^{3}$ However, the defects of this specification are also very obvious. Since this article uses miscellaneous provisions like "others", actually to implement all preparatory acts such as "preparing tools and manufacturing conditions" for committing terrorist activities. Such unprecedented legislative style, despite the aforesaid restrictions on types, still covers too broad scope. In order to prevent the article from forming ultra-wide pocket crimes in practical applications, the basic constraint is to use the ejusdem generis rule to restrict the voluntary expansion of miscellaneous provisions. Only when they are generally homogenous in nature, identical in value, or of similar value can the same explanation be made. In this way, the citizens have the possibility of predicting and can protect their basic rights from infringement. Therefore, in the interpretation of the conclusions, the "other tools" prepared for committing terrorist activities must have the same danger as the previously shown dangerous goods such as weapons. Besides, "other preparations" for committing terrorist activities also need to have concrete and direct urgency in the nature of acts such as the preparation of tools, training, personnel contact, implementation and planning.

\section{SUBJECTIVE UNDERSTANDING OF CRIME}

This crime is expressed as intentional in subjective aspect and can only be direct intent. Negligence or indirect intent cannot constitute this crime. Some people think that the purpose of committing terrorist activities is the subjective premise of the first, third, and fourth acts described below, and the absence of this purpose does not constitute this crime.

Che Hao. Reflections on the legal dogmatics of criminal legislation - focusing on Criminal Law Amendment (XI) [J]. Law Science, 2015, (10):11.
Whereas the second act, namely the organization of training for terrorist activities or active participation in training for terrorist activities, does not require evidence to prove that the actor has the purpose of committing terrorist activities, and the harmfulness of the act itself is sufficient to equal the other three acts of the crime.

In view of this, I believe that in terms of crime terms, legislative objectives, and objective constituent elements, the purpose of committing terrorist activities is the subjective characteristic of this crime, and all the four acts need to meet this requirement. This is not explicitly stated in the second situation because the act of "organizing training or actively participating in training for terrorist activities" can basically be presumed to be subjectively aware that the act is related to the implementation of terrorist activities compared to the other three situations. If the actor participates in training for terrorist activities, but he/she is subjectively unaware that the training is related to terrorist activities, it is not in conformity with this crime not because there is no subjective aspect, but it can be objectively identified that he/she does not organize or actively participate as to achieve the effect of decriminalization. The other three situations are often similar in appearance to the acts in ordinary daily life. Therefore, the acts such as the preparation of tools, connection with overseas organizations and individuals, and planning need to be differentiated from activities in ordinary daily life. Therefore, it is necessary to emphasize the "the purpose of committing terrorist activities" to remind the judiciary personnel, thereby limiting the scope of penalties. Therefore, if the actor objectively implements the acts such as the preparation of weapons and dangerous goods, connection with overseas terrorist organizations and terrorists, but is subjectively unaware that the goods he/she prepares, the organization and personnel he/she connects are involved in committing terrorist activities, or he/she thinks that it is an ordinary crime; it cannot be convicted as this crime.

\section{OTHER ISSUES IN JUDICIAL APPLICATION}

\section{A. Judgment of Severity of the Situation}

The determination of "severity of the situation" requires comprehensive judgment. Generally, it refers to preparation of a large number of weapons and dangerous goods, a large number of training personnel, frequent connection with overseas terrorist organizations, long-term gathering of a large number of people, and multiple planning, and preparation for an attack, which may result in major personnel casualties and major damage to goals. In judicial practice, judiciary authorities can determine according to the specific situation of the case, and specific regulations can also be made by formulating relevant judicial interpretations when necessary.

\section{B. Number of Crimes}

This crime punishes preparatory acts of committing terrorist activities. In practice, the actor may have started to commit terrorist activities when he/she is captured. For

Zhao Bingzhi,Understanding and Application of the Criminal Law Amendment of the People's Republic of China (XI). China Legal Publishing House, 2016.113. 
example, the actor creates, buys, sells, transports, and stores guns, ammunition, explosives, or dangerous substances in preparation for the commission of a terrorist activity; incites the training objects to commit crimes of splitting the country and subverting the state power, and imparts gun making and explosive making technology or teaches other crime methods; illegally obtains state secrets, intelligence, etc. by stealing, spying, bribing, etc. during the planning and other preparations. For these criminal acts, if there is a competing situation with the criminal acts specified in this paragraph, the punishment shall be convicted according to the heavier penalty provisions. In terms of understanding of this article, there are views that absorbable offence shall be established: if the actor has started to commit specific terrorist activities, such as intentional killings, explosions, etc., the latter crime and the former crime of preparing to commit the terrorist activities constitute several crimes. Because the actor has implemented more than one action, it does not involve the issue of joinder of offenses or imaginative joinder of offenses. Since the former criminal act is a preparatory act for the latter criminal act, and the close relationship between them determines that they are not implicated and meet the definition of absorbable offence. There are views that this crime is a type of crime formed by the categorization of preparatory acts of related crimes. Therefore, the boundary between this crime and other terrorist activities lies in that the crime is only preparation for committing other terrorist activities, but it has not reached the stage of committing other crimes. If it constitutes both the crime and other crimes, it belongs to imaginative joinder of offenses, and the heavier crime shall be selected and convicted.5I believe that it is not necessary to discuss its legal ownership in judicial practice, but only needs to convict "by the heavier crime" in accordance with the regulations". This is in line with the reality of cracking down on terrorist activities. It is not entangled in theoretical disputes but punishes the crimes to crackdown on terrorist activities.

\section{CONCLUSION}

Cracking down on terrorism by law is a major criminal issue faced by the whole world. On this basis, all countries are strengthening their anti-terrorism legislation. The crime preparation for committing terrorist activities is a very important part of China's anti-terrorism criminal justice process. Acts cannot be done on its own. Only by accurately interpreting and grasping this newly-increased crime can China achieve good law and good governance in the fight against and prevention of terrorist activities.

\section{REFERENCES}

[1] Chief Editor: Zhao Bingzhi, Understanding and Application of the Criminal Law Amendment of the People's Republic of China (XI). China Legal Publishing House, 2016.112. 赵秉志主编:《中华人民共 和国刑法修正案 (九) 》理解与适用.中国法制出版社,2016.112.

[2] Zhang Mingkai. On the provisions of the Criminal Law Amendment (IX) on terrorist crimes [J]. Modern Law Science, 2016, 38(01):29. 张明楷. 论《刑法修正案 (九)》关于恐怖犯罪的规定 [J]. 现代法 学, 2016,38(01):29.

[3] Che Hao. Reflections on the legal dogmatics of criminal legislation focusing on Criminal Law Amendment (XI) [J]. Law Science, 2015,
(10):11. 车浩. 刑事立法的法教义学反思一一以《刑法修正案 (九) 》为中心 $[J]$.法学, $2015,(10): 11$.

[4] Zhao Bingzhi, Understanding and Application of the Criminal Law Amendment of the People's Republic of China (XI). China Legal Publishing House, 2016.113. 赵秉志.《中华人民共和国刑法修正案 （九）》理解与适用.中国法制出版社,2016.113.

[5] Shi Yanan. Interpretation and Application of the Criminal Law Amendment of the People's Republic of China (XI). People's Court Press, 2015.88. 时延安. 《中华人民共和国刑法修正案（九）》解释 与适用.人民法院出版社,2015.88. 